\title{
Pengaruh Jam Kerja Dan Disiplin Kerja Terhadap Stres Kerja Karyawan di Kantor Kecamatan Kapongan Kabupaten Situbondo
}

\author{
Lusiana Tulhusnah \\ Universitas Abdurachman Saleh \\ Lusianatulhusnah17@gmail.com \\ Puryantoro \\ Universitas Abdurachman Saleh \\ puryantorounars@gmail.com
}

\begin{abstract}
Abstrak
Penelitian ini bertujuan untuk mengetahui pengaruh jam kerja dan disiplin kerja terhadap stres kerja karyawan di Kantor Kecamatan Kapongan Situbondo. Metode pengumpulan data dilakukan dengan metode penyebaran kuesioner kepada para karyawan kantor kecamatan kapongan situbondo. Teknik Analisa Data yang digunakan adalah Regresi Linear Berganda, Uji F ( $F$-test) serta Uji t $(t$-Test). Penelitian ini terbagi kedalam dua variabel yaitu jam kerja $\left(\mathrm{X}_{1}\right)$, disiplin kerja $\left(\mathrm{X}_{2}\right)$ sedangkan untuk variabel terikat yaitu stres Kerja karyawan (Y). Berdasarkan hasil secara persial diketahui bahwa hasil $t_{\text {hitung }}$ dan $t_{\text {tabel }}$ yang menunjukkan bahwa variabel jam kerja $\left(X_{1}\right) t_{\text {hitung }}(5,289)>t_{\text {tabel }}$ $(2,011)$. kerja mempunyai pengaruh yang positif terhadap stres kerja karyawan (Y), Hal ini juga diperkuat dengan nilai signifikan $0.000<0,05$. Artinya variabel jam kerja berpengaruh signifikan terhadap stres kerja karyawan pada Kantor Kecamatan Kapongan Situbondo. Sedangkan variabel disiplin kerja $\left(\mathrm{X}_{2}\right) \mathrm{t}_{\text {hitung }}(1,792)<\mathrm{t}_{\text {tabel }}$ $(2,011)$, Hal ini juga diperkuat dengan nilai signifikan 0,080>0,05 artinya variabel Disiplin kerja tidak berpengaruh signifikan terhadap stress kerja karyawan pada Kantor Kecamatan Kapongan Situbondo.
\end{abstract}

Kata Kunci Jam Kerja, Disiplin Kerja, Stres Kerja

\section{PENDAHULUAN}

Setiap instansi pemerintah dituntut untuk dapat mengoptimalkan sumberdaya manusia dan bagaimana sumber daya manusia dikelola.Pengelolaan sumber daya manusia tidak lepas dari faktor pegawai yang diharapkan dapat berprestasi sebaik mungkin demi mencapai tujuan instansi pemerintah.Pegawai merupakan asset utama instansi dan mempunyai peran yang strategis di dalam instansi yaitu sebagai pemikir, perencana, dan pengendali aktivitas instansi.

Demi tercapainya tujuan instansi, pegawai memerlukan disiplin untuk bekerja lebih rajin. Melihat pentingnya pegawai dalam instansi, maka pegawai diperlukan perhatian lebih serius terhadap tugas yang dikerjakan sehingga tujuan instansi tercapai, dengan disiplin kerja yang tinggi pegawai akan bekerja lebih giat didalam melaksanakan pekerjaannya. Sebaliknya apabila disiplin kerja yang rendah pegawai tidak mempunyai semangat bekerja, mudah menyerah, dan kesulitan dalam menyelesaikan 
pekerjaannya.Pegawai kurang memiliki informasi yang jelas apakah pekerjaan mereka memiliki dampak positif terhadap para penerima manfaatnya yaitu individu atau kelompok yang dilayani instansi.Signifikansi tugas seringkali tidak pasti di instansi instansi karena beberapa alasan.Pertama pegawai di instansi sering menemui prasangka buruk, yang bisa menghalangi mereka untuk merasa bahwa mereka telah mencapai tujuan - tujuan dan membuat mereka ragu apakah misi mereka. Kedua para pegawai seringkali hanya menerima umpan balik langsung yang sedikit tentang bagaimana tindakan mereka mempengaruhi penerima manfaat yang mungkin membuat mereka ragu apakah misi mereka tercapai atau tidak.

Selain faktor disiplin kerja, jam kerja dapat mempengaruhi terjadinya stres kerja di berbagai instansi. Jam Kerja adalah kondisi - kondisi material dan psikologis yang ada dalam instansi.

Instansi untuk meningkatkan hasil kinerja karyawan, diantaranya adalah dengan memperhatikan stres kerja. Stress merupakan suatu kondisi keadaan seseorang mengalami ketegangan karena adanya kondisi yang mempengaruhinya, kondisi tersebut dapat diperoleh dari dalam diri seseorang maupun lingkungan diluar seseorang. Stress dapat menimbulkan dampak yang negatif terhadap keadaan psikologis dan biologis bagi karyawan. Menurut Robbin (2002:318) stres merupakan kondisi dinamis dimana seseorang individu dihadapkan dengan kesempatan, keterbatasan atau tuntutan sesuai dengan harapan dari hasil yang ingin dia capai dalam kondisi penting dan tidak menentu. Menurut Sari (2003:205) meneliti tentang pengaruh sumber-sumber stress kerja terhadap kinerja karyawan yang menunjukkan bahwa individual stress berpengaruh paling dominan terhadap hasil kinerja sebuah instansi.

Berdasarkan latar belakang tersebut, maka perlu dikaji Pengaruh Jam Kerja Dan Disiplin Kerja Terhadap Stres Kerja Karyawan (Study Kasus Pada Kantor Kecamatan Kapongan Situbondo)

\section{LANDASAN TEORI}

\subsection{Jam Kerja}

Jam kerja merupakan bagian dari empat faktor organisasi yang merupakan sumber potensial dari stres para karyawan di tempat kerja (Robbins,2002). Davis dan Newstrom (dalam Imatama, 2006:4) menyatakan adanya beberapa karakteristik pekerjaan dan lingkungan kerja yang mengandung stres kerja yang salah satunya adalah terbatasnya waktu dalam mengerjakan pekerjaan. Jam kerja "normal" umumnya diartikan hari kerja dengan jam tersisa untuk rekreasi dan istirahat. Istirahat adalah kegiatan malam hari, sedangkan bekerja adalah aktivitas siang hari. Hal ini berkaitan dengan mereka yang bekerja dengan jadwal yang tidak biasa, baik pada shift kerja atau dengan jam yang diperpanjang hingga melampaui siang, bekerja pada malam hari, serta bekerja disaat pola tidur (Harrington, 2001. Jam kerja adalah waktu yang ditentukan untuk melakukan pekerjaan. Harrington (2001 : 12) juga menyatakan bahwa lamanya jam kerja berlebih dapat meningkatkan human error atau kesalahan kerja karena kelelahan yang meningkat dan jam tidur yang berkurang. Hal tersebut juga didukung oleh penelitian Berger,et.al (2006:29) dalam Maurits dan Widodo (2008:42) yang menyatakan bahwa tambahan durasi pada suatu shift kerja, akan meningkatkan tingkat kesalahan. Lima kali tambahan durasi shift per bulan akan meningkatkan kelelahan 300\% dan berakibat fatal.

Karyawan biasanya mempunyai kemampuan normal menyelesaikan tugas kantor / perusahaan yang dibebankan kepadanya, kemampuan berkaitan dengan keahlian, pengalaman, dan waktu yang dimiliki. Dalam kondisi tertentu, pihak atasan seringkali 
memberikan tugas dengan waktu yang terbatas . Akibatnya karyawan dikejar waktu untuk menyelesaikan tugas tepat waktu sesuai yang ditetapkan atasan.

Waktu kerja merupakan bagian dari empat faktor organisasi yang merupakan sumber potensial dari stres para karyawan di tempat kerja (Robbins, 2006:796). Davis dan Newstrom (dalam Imatama, 2006:4) menyatakan adanya beberapa karakteristik pekerjaan dan lingkungan kerja yang mengandung stres kerja yang salah satunya adalah terbatasnya waktu dalam mengerjakan pekerjaan.

Karyawan biasanya mempunyai kemampuan normal menyelesaikan tugas kantor / perusahaan yang dibebankan kepadanya, kemampuan berkaitan dengan keahlian, pengalaman, dan waktu yang dimiliki. Dalam kondisi tertentu, pihak atasan seringkali memberikan tugas dengan waktu yang terbatas . Akibatnya karyawan dikejar waktu untuk menyelesaikan tugas tepat waktu sesuai yang ditetapkan atasan.

\subsection{Disiplin Kerja}

Untuk mencapai tujuan organisasi diperlukan kerja sama yang serasi dalam tim kerja dan kesadaran yang tinggi bagi setiap anggota organisasi untuk bekerja sama secara bersungguh-sungguh serta patuh terhadap peraturan yang telah disepakati. Secara umum kedisiplinan seseorang dapat dilihat dari perilaku orang tersebut dalam menjalankan tugasnya.Secara lebih mendalam kedisiplinan memuat dimensi sikap yang melibatkan mental seseorang.

Ada beberapa definisi tentang disiplin yang dikemukakan oleh para ahli antara lain, Menurut Mangkunegara (2001:129) :"Dicipline is management action to enforce organization standar". (Disiplin kerja adalah pelaksanaan manajemen untuk memperteguh pedoman-pedoman organisasi). Menurut Rivai (2004) :'Disiplin kerja adalah suatu alat yang digunakan para manajer untuk berkomunikasi dengan karyawan agar mereka bersedia untuk mengubah suatu perilaku serta sebagai suatu upaya untuk meningkatkan kesadaran dan kesediaan seseorang mentaati semua peraturan perusahaan dan norma-norma sosial yang berlaku". Adapun menurut Mathis dan Jackson (2002:314) : "Disiplin karyawan dapat dipandang sebagai suatu penerapan modifikasi perilaku untuk karyawan bermasalah atau karyawan yang tidak produktif “. Sedangkan menurut Poerwadarminta (2006) " Disiplin adalah watak dan batin agar segala perbuatan seseorang sesuai dengan peraturan yang ada".

Dari beberapa devinisi diatas dapat kita simpulkan bahwasannya disiplin kerja adalah merupakan bentuk pelatihan yang menegakkan peraturan-peraturan perusahaan.Disiplin kerja yang baik mencerminkan besarnya tanggung jawab seseorang terhadap tugas-tugas yang diberikan kepadanya.Hal ini mendorong gairah kerja, semangat kerja, dan terwujudnya tujuan perusahaan, karyawan, serta masyarakat pada umumnya.

\subsection{Stres Kerja}

Stres merupakan suatu kondisi ketegangan yang mempengaruhi emosi, proses berpikir, dan kondisi seseorang dimana karyawan terpaksa memberikan tanggapan melebihi kemampuan penyesuaian dirinya terhadap suatu tuntutan eksternal (lingkungan) (Siregar, 2006:19).Menurut Nimran (dalam Siregar, 2006:17), ada beberapa alasan mengapa masalah stres yang berkaitan dengan organisasi perlu diselesaikan pada saat ini. Di antaranya adalah :

1. Masalah stres adalah masalah yang akhir-akhir ini sering dibicarakan, dan posisinya sangat penting dalam kaitannya dengan produktifitas kerja karyawan. 
2. Selain dipengaruhi oleh faktor-faktor yang bersumber dari luar organisasi, stres juga banyak dipengaruhi oleh faktor-faktor yang berasal dari dalam organisasi. Oleh karena itu, perlu disadari dan dipahami keberadaannya.

3. Pemahaman akan sumber-sumber stres yang disertai dengan pemahaman terhadap cara-cara mengatasinya, adalah penting sekali bagi karyawan dan siapa saja yang terlibat dalam organisasi demi kelangsungan organisasi yang sehat dan efektif.

4. Individu pasti merupakan bagian dari satu atau beberapa organisasi, baik sebagai atasan maupun sebagai bawahan, pernah mengalami stres meskipun dalam taraf yang amat rendah.

5. Zaman kemajuan di segala bidang seperti sekarang ini menuntut manusia untuk mempunyai kinerja yang lebih baik. Peralatan kerja yang semakin modern dan efisien, dan di lain pihak beban kerja pada satuan organisasi juga semakin bertambah sehingga menuntut energi karyawan lebih besar dari sebelumnya. Dampak dari fenomena ini adalah stres kerja yang meningkat.

Spielberg (dalam Imatama, 2006:17) mengatakan bahwa stres adalah tuntutan-tuntutan eksternal yang mengenai seseorang, misalnya obyek-obyek dalam lingkungan atau stimulus yang secara obyektif adalah berbahaya. Stres juga bisa diartikan sebagai tekanan, ketegangan, atau gangguan yang tidak menyenangkan yang berasal dari luar diri seseorang.

Masalah stres kerja penting diamati di dalam organisasi perusahaan sejak mulai timbulnya tuntutan untuk efisiensi dan efektifitas di dalam pekerjaan.Alasannya sepenuhnya bersifat bisnis.Perusahaan menginginkan kepuasan konsumen untuk meningkatkan keuntungan. Semakin baik pelayanan yang diberikan akan mengakibatkan aliran dana yang masuk. Stres kerja disebabkan adanya ketidakseimbangan antara karakteristik kepribadian karyawan dengan karakteristik aspek-aspek pekerjaannya dan dapat terjadi pada semua kondisi pekerjaan, adanya beberapa atribut tertentu mampu mempengaruhi daya tahan stres seorang karyawan.Stres kerja karyawan perlu dikelola oleh seorang pimpinan perusahaan, agar potensi-potensi yang merugikan perusahaan dapat diatasi. Pimpinan dan manager juga menginginkan hal yang terbaik, kesejahteraan bagi karyawannya didalam maupun diluar tempat kerja.

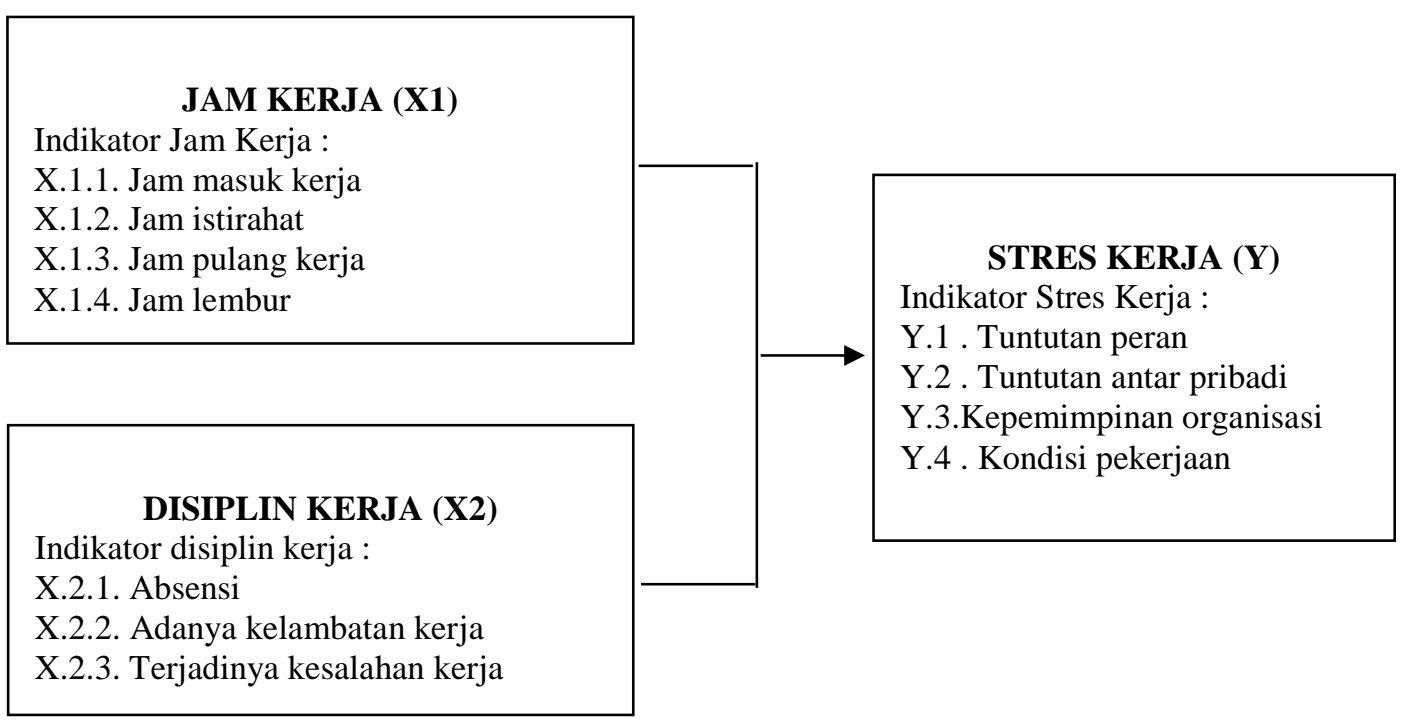




\section{Gambar 2.3 Kerangka Pemikiran}

\section{METODOLOGI PENELITIAN}

Penelitian ini menggunakan metode kuantitatif. seluruh Karyawan di Kantor Kecamatan Kapongan Situbondo yang berjumlah 50 karyawan. Teknik pengambilan sampel yang dilakukan adalah teknik sensus sampling dimana semua anggota populasi dijadikan sampel dalam penelitian. Data dikumpulkan dengan cara wawancara dan kuisioner.

Variabel bebas (Independent) dalam penelitian ini adalah $\mathrm{X}_{1} \mathrm{Jam}$ Kerja dan $\mathrm{X}_{2}$ Disiplin Kerja.Variabel terikat (Dependent) dalam penelitian ini adalah (Y) Stres kerja. Untuk mengetahui pengaruh variabel bebas terhadap variabel digunakan rumus analisis regresi linier berganda.

\section{HASIL PENELITIAN}

Hasil penelitian yang menjelaskan mengenai faktor-faktor yang mempengaruhi berupa jam kerja $\left(\mathrm{X}_{1}\right)$ dan disiplin kerja $\left(\mathrm{X}_{2}\right)$, terhadap stres Kerja $(\mathrm{Y})$ berdasarkan tanggapan responden sebagai kelayakan responden dalam memberikan informasi terhadap pertanyaan kuesioner yang diajukan. Dalam kuesioner terdapat indikator pertanyaan diberi jawaban yang terdiri dari 5 kategori.

Nilai skor ::

1 Sangat Tidak Setuju (STS) $=1$

2 Tidak Setuju (TS) $=2$

3 Netral / Ragu-ragu $(\mathrm{N})=3$

4 Setuju $(\mathrm{S}) \quad=4$

5 Sangat Setuju $(\mathrm{SS})=5$

\subsection{Variabel Jam Kerja $\left(\mathrm{X}_{1}\right)$}

Dengan indikator pernyataan sebagai berikut:

$\mathrm{X}_{1.1}$ Target yang dicapai sudah sesuai dengan waktu kerja di Kantor saya

$\mathrm{X}_{1.2}$ Pelaksanaan pekerjaan sesuai dengan waktu kerja saya

$\mathrm{X}_{1.3}$ Beban kerja sudah sesuai dengan waktu kerja saya

$\mathrm{X}_{1.4}$ Saya selalu dikejar waktu untuk mengerjakan pekerjaan saya

Tabel 1. Hasil Penilaian Responden (Jam Kerja $\left(\mathrm{X}_{1}\right)$ )

\begin{tabular}{|c|c|c|c|}
\hline \multicolumn{4}{|c|}{ Jam Kerja (X1) } \\
\hline Indikator & Skala Likert & Frekuwensi & Persentase $\%$ \\
\hline \multirow{5}{*}{$\mathrm{X}_{1.1}$} & 2 & 6 & 12,0 \\
\hline & 3 & 22 & 44,0 \\
\hline & 4 & 21 & 42,0 \\
\hline & 5 & 1 & 2,0 \\
\hline & Total & 50 & 100 \\
\hline \multirow{6}{*}{$\mathrm{X}_{1.2}$} & 1 & 1 & 2,0 \\
\hline & 2 & 9 & 18,0 \\
\hline & 3 & 25 & 50,0 \\
\hline & 4 & 12 & 24,0 \\
\hline & 5 & 3 & 6,0 \\
\hline & Total & 50 & 100 \\
\hline
\end{tabular}




\begin{tabular}{cccc}
\hline & 2 & 7 & 14,0 \\
\cline { 2 - 4 } & 3 & 20 & 40,0 \\
\cline { 2 - 4 } $\mathrm{X}_{1.3}$ & 4 & 21 & 42,0 \\
\cline { 2 - 4 } & 5 & 2 & 4,0 \\
\cline { 2 - 4 } & Total & 50 & 100 \\
\cline { 2 - 4 } & 2 & 9 & 18,0 \\
\cline { 2 - 4 } $\mathrm{X}_{1.4}$ & 3 & 15 & 30,0 \\
\cline { 2 - 4 } & 4 & 26 & 52,0 \\
\cline { 2 - 4 } & Total & 50 & 100 \\
\hline
\end{tabular}

Berdasarkan data diatas menunjukkan bahwa indikator $\left(\mathrm{X}_{1.1}\right)$, nilai terendah 2 (tidak setuju) sebanyak 6 orang responden atau $12,0 \%$, nilai 3 (netral) sebanyak 22 orang responden atau $44,0 \%$, nilai 4 (setuju) sebanyak 21 orang atau $42,0 \%$ dan nilai tertinggi 5 (sangat setuju) sebanyak 1 orang responden atau 2,0\%. Indikator $\left(\mathrm{X}_{1.2}\right)$, nilai terendah 1 (Sangat tidak setuju) sebanyak 1 orang responden atau 2,0\% nilai 2 (tidak setuju) sebanyak 9 orang responden atau $18,0 \%$ dan nilai 3 (netral) sebanyak 25 orang responden atau $50,0 \%$, nilai 4 (setuju) 12 orang responden atau sebanyak $24,0 \%$, nilai tertinggi 5 (sangat setuju) sebanyak 3 orang responden atau $6,0 \%$. indikator $\left(\mathrm{X}_{1.3}\right)$, nilai terendah 2 (tidak setuju) sebanyak 7 orang responden atau 14,0\%, nilai terendah 3 (netral) sebanyak 20 orang responden atau 40,0\%, nilai 4 (setuju) sebanyak 21 orang responden atau $42,0 \%$ dan nilai tertinggi 5 (sangat setuju) sebanyak 2 orang responden atau 4,0\%. indikator $\left(\mathrm{X}_{1.4}\right.$ ),nilai terrendah 2 (tidak setuju) sebanyak 9 orang responden atau $18,0 \%$, nilai terendah 3 (netral) sebanyak 15 orang responden atau 30,0\%, dan nilai tertinggi 4 (setuju) sebanyak 26 orang responden atau 52,0\%.

\subsection{Variabel Disiplin Kerja (X2)}

Dengan indikator pernyataan sebagai berikut:

$\mathrm{X}_{2.1}$ Ketepatan waktu saya diperlukan dalam perusahaan

$\mathrm{X}_{2.2}$ Kepatuhan saya diperlukan dalam perusahaan

$\mathrm{X}_{2.3}$ Saya mampu menyelesaikan pekerjaan dengan tepat waktu

Table 2. Hasil Penilaian Responden (Disiplin Kerja $\left(\mathrm{X}_{2}\right)$ )

\section{Disiplin Kerja $\left(\mathrm{X}_{2}\right)$}

\begin{tabular}{|c|c|c|c|}
\hline Indikator & Skala Likert & Frekuwensi & Persentase $\%$ \\
\hline \multirow{5}{*}{$\mathrm{X}_{2.1}$} & 2 & 1 & 2,0 \\
\hline & 3 & 22 & 44,0 \\
\hline & 4 & 24 & 48,0 \\
\hline & 5 & 3 & 6,0 \\
\hline & Total & 50 & 100 \\
\hline \multirow{5}{*}{$\mathrm{X}_{2.2}$} & 2 & 1 & 2,0 \\
\hline & 3 & 7 & 14,0 \\
\hline & 4 & 35 & 70,0 \\
\hline & 5 & 7 & 14,0 \\
\hline & Total & 50 & 100 \\
\hline
\end{tabular}




\begin{tabular}{cccc} 
& 3 & 16 & 32,0 \\
\cline { 2 - 4 } $\mathrm{X}_{2.3}$ & 4 & 27 & 54,0 \\
\cline { 2 - 4 } & 5 & 7 & 14,0 \\
\cline { 2 - 4 } & Total & 50 & 100
\end{tabular}

Berdasarkan data diatas menunjukkan bahwa indikator $\left(\mathrm{X}_{2.1}\right)$, nilai terendah 2 (tidak setuju) sebanyak 1 orang responden atau 2,0\%, nilai 3 (netral) sebanyak 22 orang responden atau 44,0\%, nilai 4 (setuju) sebanyak 24 orang responden atau 48,09\% dan nilai tertinggi 5 (sangat setuju) sebanyak 3 orang responden atau 6,0\%. Indikator $\left(\mathrm{X}_{2.2}\right)$, nilai terendah 2 (tidak setuju) sebanyak 1 orang responden atau 2,0\% dan nilai 3 (netral) sebanyak 7 orang responden atau 14,0\%, nilai 4 (setuju) 35 orang responden atau sebanyak $70,0 \%$, dan nilai tertinggi 5 (sangat setuju) sebanyak 7 orang responden atau $14,0 \%$. indikator $\left(\mathrm{X}_{2.3}\right)$, nilai terendah 3 (netral) sebanyak 16 orang responden atau $32,0 \%$, nilai 4 (setuju) sebanyak 27 orang responden atau 54,0\% dan nilai tertinggi 5 (sangat setuju) sebanyak 7 orang responden atau $14,0 \%$.

\subsection{Variabel Stres Kerja Karyawan (Y)}

Dengan indikator pernyataan sebagai berikut:

$\mathrm{Y}_{1} \quad$ Tuntutan tugas yang berat dapat memotivasi saya untuk lebih maju

$\mathrm{Y}_{2}$ Dalam bekerja, saya tidak dapat memberikan pelayanan yang memuaskan

$\mathrm{Y}_{3}$ Tekanan di perusahaan membuat saya lebih fokus dalam bekerja

$\mathrm{Y}_{4}$ Banyaknya pekerjaan membuat saya menyelesaikannya secara terburu-buru

Tabel 3. Penilaian Responden (Stres Kerja Karyawan (Y)

\begin{tabular}{|c|c|c|c|}
\hline \multicolumn{4}{|c|}{ Stres Kerja Karyawan (Y) } \\
\hline Indikator & Skala Likert & Frekuwensi & persentase $\%$ \\
\hline \multirow{4}{*}{$Y_{1}$} & 3 & 12 & 24,0 \\
\hline & 4 & 30 & 60,0 \\
\hline & 5 & 8 & 16,0 \\
\hline & Total & 50 & 100 \\
\hline \multirow{5}{*}{$\mathrm{Y}_{2}$} & 2 & 1 & 2,0 \\
\hline & 3 & 2 & 4,0 \\
\hline & 4 & 37 & 74,0 \\
\hline & 5 & 10 & 20,0 \\
\hline & Total & 50 & 100 \\
\hline \multirow{4}{*}{$\mathrm{Y}_{3}$} & 3 & 4 & 8,0 \\
\hline & 4 & 32 & 64,0 \\
\hline & 5 & 14 & 28,0 \\
\hline & Total & 50 & 100 \\
\hline \multirow{5}{*}{$\mathrm{Y}_{4}$} & 2 & 1 & 2,0 \\
\hline & 3 & 1 & 2,0 \\
\hline & 4 & 36 & 72,0 \\
\hline & 5 & 12 & 24,0 \\
\hline & Total & 90 & 100 \\
\hline
\end{tabular}


Berdasarkan data diatas menunjukkan bahwa indikator (Y.1), nilai terendah 3 (netral) sebanyak 12 orang responden atau 24,0\%, nilai 4 (setuju) sebanyak 30 orang responden atau $60,0 \%$ dan nilai tertinggi 5 (sangat setuju) sebanyak 8 orang responden atau $16,0 \%$. Indikator $\left(\mathrm{Y}_{2}\right)$, nilai terendah nilai terendah 2 (tidak setuju) sebanyak 1 orang responden atau 2,0\% dan nilai 3 (netral) sebanyak 2 orang responden atau 4,0\%, nilai 4 (setuju) 37 orang responden atau sebanyak 74,0\%, nilai tertinggi 5 (sangat setuju) sebanyak 10 orang responden atau 20,0,7\%. indikator lain $\left(\mathrm{Y}_{3}\right)$,nilai terendah terendah 3 (netral) sebanyak 4 orang responden atau 8,0\%, nilai 4 (setuju) sebanyak 32 orang responden atau $64,0 \%$ dan nilai tertinggi 5 (sangat setuju) sebanyak 14 orang responden atau 28,0\%. indikator $\left(\mathrm{Y}_{4}\right.$ ),nilai terendah 2 (tidak setuju) sebanyak 1 orang responden atau 2,0\%, nilai terendah 3 (netral) sebanyak 1 orang responden atau 2,0\%, nilai 4 (setuju) sebanyak 36 orang responden atau 72,0\%, dan nilai tertinggi 5 (sangat setuju) sebanyak 12 orang responden atau $24,0 \%$.

\section{Uji Validitas}

Untuk menguji validitas setiap butir maka skor dari masing-masing butir dimaksud dikorelasikan dengan skor total. Skor butir, dipandang sebagai nilai $\mathrm{X}$ dan skor total dipandang sebagai Y. Dengan diperolehnya indeks validitas setiap butir dapat diketahui dengan pasti butir-butir manakah yang tidak memenuhi syarat, ditinjau dari validitasnya. Berdasarkan informasi tersebut peneliti dapat mengganti ataupun merevisi butir-butir dimaksud. Bagi peneliti yang menginginkan, pengujian terhadap butir dapat dilakukan dengan mengkorelasikan butir dengan skor total pada faktor.

Butir bisa dipakai jika nilai koefisien korelasinya positif. Oleh karena skor yang diperoleh di lapangan tingkat pengukurannya ordinal maka koefiesien korelasi. Hasil penelitian dibuat berdasarkan hasil proses pengujian data yang meliputi pemilihan, pengumpulan dan analisis data. Oleh karena itu, hasil penelitian itu tergantung pada kualitas data yang dianalisis dan instrumen yang digunakan untuk mengumpulkan data penelitian instrumen pada penelitian ini adalah kuesioner sehingga data yang diperoleh dari responden akan diuji kualitas datanya dengan menggunakan uji validitas dan uji reliabilitas.

Tabel 4. Uji Validitas Variabel

\begin{tabular}{ccccc}
\hline Nomer & Indikator & Koefisien Validitas & r Tabel & Keterangan \\
\hline 1 & $\mathrm{X}_{1.1}$ & 0,819 & 0.2787 & Valid \\
2 & $\mathrm{X}_{1.2}$ & 0,862 & 0.2787 & Valid \\
3 & $\mathrm{X}_{1.3}$ & 0,912 & 0.2787 & Valid \\
4 & $\mathrm{X}_{1.4}$ & 0,920 & 0.2787 & Valid \\
5 & $\mathrm{X}_{2.1}$ & 0,859 & 0.2787 & Valid \\
6 & $\mathrm{X}_{2.2}$ & 0,746 & 0.2787 & Valid \\
7 & $\mathrm{X}_{2.3}$ & 0,886 & 0.2787 & Valid \\
8 & $\mathrm{Y}_{1}$ & 0,737 & 0.2787 & Valid \\
9 & $\mathrm{Y}_{2}$ & 0,780 & 0.2787 & Valid \\
10 & $\mathrm{Y}_{3}$ & 0,783 & 0.2787 & Valid \\
11 & $\mathrm{Y}_{4}$ & 0,794 & 0.2787 & Valid \\
\hline
\end{tabular}

Berdasarkan Table 4 diatas dapat dilihat bahwa hasil uji validitas untuk variabel Jam Kerja $\left(\mathrm{X}_{1}\right)$ dengan $\mathrm{R}$ hitung $0,819,0,862,0,912$, dan 0,920, sedangkan $\mathrm{R}$ tabelnya adalah 0.2787 , jadi dapat disimpulkan semuanya valid. Untuk variabel Disiplin Kerja $\left(\mathrm{X}_{2}\right)$ diperoleh hasil uji validitas dengan $\mathrm{R}$ hitung 0,859 , 0,746 , dan 0,886 , sedankan $\mathrm{R}$ tabelnya adalah 0.2787, jadi dapat disimpulkan semuanya valid. Sedangkan untuk 
variabel Stres Kerja (Y) diperoleh $\mathrm{R}$ hitung 0,737, 0,780 , 0,783, dan 0,794 dengan $\mathrm{R}$ tabel 0.2787 , jadi dapat diketahui bahwa semuanya valid karena nilai $\mathrm{R}$ hitung lebih besar dari $\mathrm{R}$ tabel $=0.2787$.

\section{Uji Reliabilitas}

Uji reliabilitas tingkat kemantapan dan suatu alat ukur atau uji yang digunakan untuk mengetahui sejauh mana pengukuran relatif konsisten apabila dilakukan pengukuran ulang. Uji ini digunakan untuk mengetahui sejauh mana jawaban seseorang konsinten atau lebih dari waktu ke waktu, dalam penelitian ini pengukuran reliabilitas dilakukan dengan menggunakan metode Cronbach's Alpha, dimana kuesioner dikatakan reliable jika nilai Crombach's Alpha, dari 0,60. Hasil uji reliabelitas terlihat pada tabel berikut:

Tabel 5. Uji Reliabilitas Variabel

\begin{tabular}{cccc}
\hline Variabel & Nilai & Nilai Cut off & Keterangan \\
\hline Jam kerja $\left(\mathrm{X}_{1}\right)$ & 0,900 & 0,60 & Reliabel \\
Disiplin kerja $\left(\mathrm{X}_{2}\right)$ & 0,778 & 0,60 & Reliabel \\
Stress kerja $(\mathrm{y})$ & 0,774 & 0,60 & Reliabel \\
\hline
\end{tabular}

Dari Tabel 5 diatas dapat diketahui bahwa nilai reliabilitas dari variabel Jam Kerja $\left(\mathrm{X}_{1}\right)$ adalah 0,900, variabel Disiplin Kerja $\left(\mathrm{X}_{2}\right)$ adalah 0,778 dan variabel Stres Kerja (Y) adalah 0,774. Dari hasil tersebut dapat disimpulkan bahwa nilai dari Crombach's Alpha untuk tiga variabel lebih besar dari 0,60 yaitu Jam kerja $\left(\mathrm{X}_{1}\right)$, Disiplin kerja $\left(\mathrm{X}_{2}\right)$, dan Stres kerja (Y). Dari ketentuan yang telah disebutkan sebelumnya maka tiga variable tersebut sudah reliable.

\section{Analisis Regresi Linier Berganda}

Berdasarkan data penelitian yang dikumpulkan baik untuk variabel terikat (Y) maupun variable bebas $\left(\mathrm{X}_{1}, \mathrm{X}_{2}\right)$ yang diolah dengan menggunakan SPSS versi 17 , maka diperoleh hasil perhitungan regresi linier berganda sebagai berikut:

Tabel 6. Hasil Analisis Regresi Linier Berganda

\begin{tabular}{|c|c|c|c|c|c|c|}
\hline \multicolumn{7}{|c|}{ Coefficients $^{\mathrm{a}}$} \\
\hline \multirow{2}{*}{\multicolumn{2}{|c|}{ Model }} & \multicolumn{2}{|c|}{ Unstandardized Coefficients } & $\begin{array}{l}\text { Standardized } \\
\text { Coefficients }\end{array}$ & \multirow[b]{2}{*}{$\mathrm{t}$} & \multirow[b]{2}{*}{ Sig. } \\
\hline & & $\mathrm{B}$ & Std. Error & Beta & & \\
\hline 1 & (Constant) & 5.185 & .108 & & .000 & 1.000 \\
\hline & Jam Kerja & .591 & .112 & .591 & 5.289 & .000 \\
\hline & Disiplin Kerja & .200 & .112 & .200 & 1.792 & .080 \\
\hline
\end{tabular}

a. Dependent Variable: Stres Kerja

Berdasarkan Tabel 6 diatas dapat diperoleh persamaan regresi linier berganda sebagai berikut:

$\mathrm{Y}=5,185+0,591 \mathrm{X}_{1}+0,200 \mathrm{X}_{2}+\mathrm{e}$

Dimana :

5,185E-17 = Nilai Konstan sebesar 5.185E-17 artinya apabila variabel jam kerja dan disiplin kerja diasumsikan 0, maka nilai stres kerja sebesar 5.185E-17. 
0,591 = Besarnya koefisien variabel jam kerja yang berarti setiap peningkatan variabel jam kerja 1\% maka stress kerja meningkat sebesar 0,591 dengan asumsi variable lainnya (disiplin kerja) konstan.

$0,200=$ Besarnya koefisien variabel disiplin kerja yang berarti setiap peningkatan variabel disiplin kerja sebesar 1\%, maka stres kerja meningkat sebesar 0,200 dengan asumsi variable lainnya (jam kerja) konstan.

e $=$ Nilai kesalahan dari model persamaan regresi yang disebabkan oleh variabel lain yang mempengaruhi stress kerja, e sebesar 0,108 .

\section{Uji Statistik Persial (t)}

Mengetahui pengaruh masing - masing faktor independen, yaitu variable jam kerja $\left(\mathrm{X}_{1}\right)$, disiplin kerjai $\left(\mathrm{X}_{2}\right)$ berpengaruh signifikan terhadap stress kerja karyawan $(\mathrm{Y})$ digunakan uji $\mathrm{t}(\mathrm{t}-$ test) dua arah (two side atau 2 - tail test) dengan cara membandingkan nilai $\mathrm{t}_{\text {hitung dengan }} \mathrm{t}_{\mathrm{tabel}}$ dengan derajat kebebasan (degree of freedom) sebesar $90 \%(\alpha=$ $5 \%$ ) diperoleh $t$ tabel sebesar dibawah disajikan hasil perbandingan antara nilai $t$ hitung dengan $t_{\text {tabel. }}$.

Tabel 7. Perbandingan Antara Nilai $t_{\text {hitung dengan }} t_{\text {table }}$

Coefficients $^{\mathbf{a}}$

\begin{tabular}{|c|c|c|c|c|c|c|}
\hline \multirow{2}{*}{\multicolumn{2}{|c|}{ Model }} & \multicolumn{2}{|c|}{ Unstandardized Coefficients } & $\begin{array}{l}\text { Standardized } \\
\text { Coefficients }\end{array}$ & \multirow[b]{2}{*}{$\mathrm{t}$} & \multirow[b]{2}{*}{ Sig. } \\
\hline & & B & Std. Error & Beta & & \\
\hline 1 & (Constant) & $5.185 \mathrm{E}-17$ & .108 & & .000 & 1.000 \\
\hline & Jam Kerja & .591 & .112 & .591 & 5.289 & .000 \\
\hline & Disiplin Kerja & .200 & .112 & .200 & 1.792 & .080 \\
\hline
\end{tabular}

a. Dependent Variable: Stres Kerja

\section{Jam Kerja $\left(\mathrm{X}_{1}\right)$}

Nilai thitung untuk variabel jam kerja ini sebesar 5,289. Sementara itu nilai pada $t_{\text {tabel }}$ Distribusi 5\% sebesar 2,011, maka $t_{\text {hitung }}(5,289)>t_{\text {tabel }}(2,011)$. Hal ini berarti variabel jam kerja mempunyai pengaruh yang positif. Hal ini juga diperkuat dengan nilai signifikan $0.000<0,05$ Artinya variabel jam kerja berpengaruh signifikan terhadap stres kerja karyawan pada Kantor Kecamatan Kapongan Situbondo, maka Ha diterima dan Ho Ditolak.

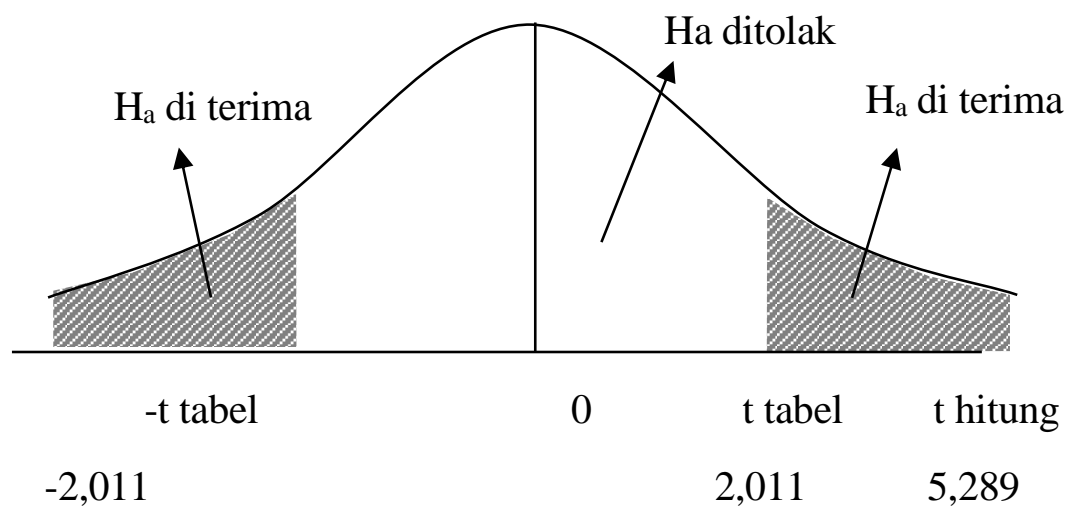

Gambar 2. Kurva Distribusi Normal Untuk Jam Kerja 


\section{Disiplin Kerja $\left(\mathrm{X}_{2}\right)$}

Nilai thitung untuk variabel Disiplin kerja 1,792. Sementara itu nilai pada $t_{\text {tabel }}$ distribusi 5\% sebesar 2,011, maka thitung $(1,792)<t_{\text {tabel }}(2,011)$. Hal ini juga diperkuat dengan nilai signifikan 0,080>0,05 artinya variabel Disiplin kerja tidak berpengaruh signifikan terhadap stress kerja karyawan pada Kantor Kecamatan Kapongan Situbondo, maka Ho Diterima dan Ha Ditolak.

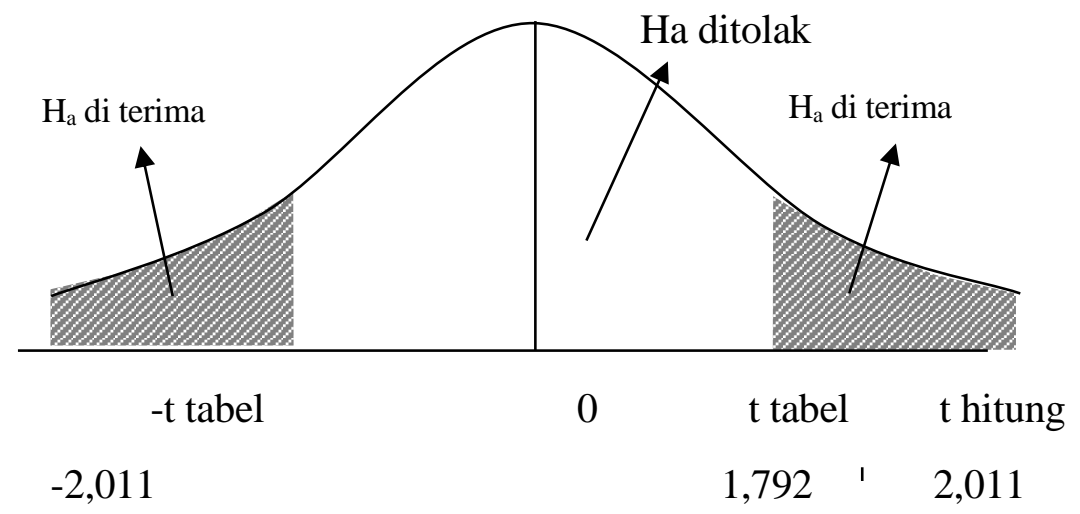

Gambar 3. Kurva Distribusi Normal Untuk disiplin kerja

\section{Uji Statistik Simultan (F)}

Uji simultan atau uji F merupakan uji secara bersama-sama untuk menguji signifikan pengaruh variabel jam kerja dan disiplin kerja terhadap stres kerja karyawan.

Tabel 8. Hasil Uji Simultan

\begin{tabular}{|c|c|c|c|c|c|c|}
\hline \multicolumn{7}{|c|}{ ANOVA $^{b}$} \\
\hline \multicolumn{2}{|c|}{ Model } & $\begin{array}{l}\text { Sum of } \\
\text { Squares }\end{array}$ & Df & Mean Square & $\mathrm{F}$ & Sig. \\
\hline 1 & Regression & 21.446 & 2 & 10.723 & 18.291 & $.000^{\mathrm{a}}$ \\
\hline & Residual & 27.554 & 47 & .586 & & \\
\hline & Total & 49.000 & 49 & & & \\
\hline
\end{tabular}

a. Predictors: (Constant), Disiplin Kerja, Jam Kerja

b. Dependent Variable: Stres Kerja

Langkah-langkah untuk melakukan uji $\mathrm{F}$, pertama yaitu menentukan hipotesis penelitian yaitu $\left(\mathrm{H}_{\mathrm{a}}\right)$ jam kerja dan disiplin kerja, berpengaruh secara simultan terhadap stres kerja karyawan pada kantor kecamatan kapongan. langkah selanjutnya kemudian menentukan Tingkat signifikan, besar tingkat signifikansi yang digunakan adalah $0.05(\alpha$ $=5 \%$ ), tingkat signifikansi sebesar 0.000 atau sebesar $0 \%$ artinya bahwa variabel independen berpengaruh terhadap variabel dependen dengan tingkat signifikansi sebesar $0 \%$. 
Besar tingkat keyakinan $95 \%, \alpha=5 \%$, df 1 dapat ditentukan dengan persamaan berikut :

df $1=$ jumlah variabel; artinya df $1=2$

df $2=\mathrm{n}-\mathrm{k}-1 ;$ artinya $\mathrm{df} 2=47 ;(50-2-1)$

maka dapat dilihat pada tabel F pada kolom 2 baris 47 yakni 3,20

Kriteria pengujian :

$\mathrm{H}_{\mathrm{a}}$ diterima jika $\mathrm{F}_{\text {hitung }}>\mathrm{F}_{\text {tabel }}$

$\mathrm{H}_{\mathrm{a}}$ ditolak jika $\mathrm{F}_{\text {hitung }}<\mathrm{F}_{\text {tabel }}$

Membandingkan $\mathrm{F}$ hitung dengan $\mathrm{F}$ tabel, nilai $\mathrm{F}$ hitung $>\mathrm{F}$ tabel $(18,291>3,20)$. Berdasarkan pengujian statistik dengan metode uji $\mathrm{F}$, di mana tingkat signifikan yang diperoleh lebih kecil yakni sebesar 0,000 dari standart signifikan yakni $5 \%$ atau 0,05 dan perbandingan antara $F_{\text {hitung }}$ dan $\mathrm{F}_{\text {tabel }}$, di mana $\mathrm{F}_{\text {hitung }}$ sebesar 18,291 lebih besar dari $\mathrm{F}_{\text {tabel }}$ yakni 3,20 maka dapat disimpulkan bahwa $\mathrm{H}_{\mathrm{a}}$ diterima dan $\mathrm{H}_{\mathrm{o}}$ ditolak yang terdiri dari jam kerja dan disiplin kerja berpengaruh secara simultan terhadap stres Kerja karyawan. Berdasarkan hasil pengolahan data yang telah dijabarkan diatas, maka dapat digambarkan dalam sebuah kurve sebagai berikut :

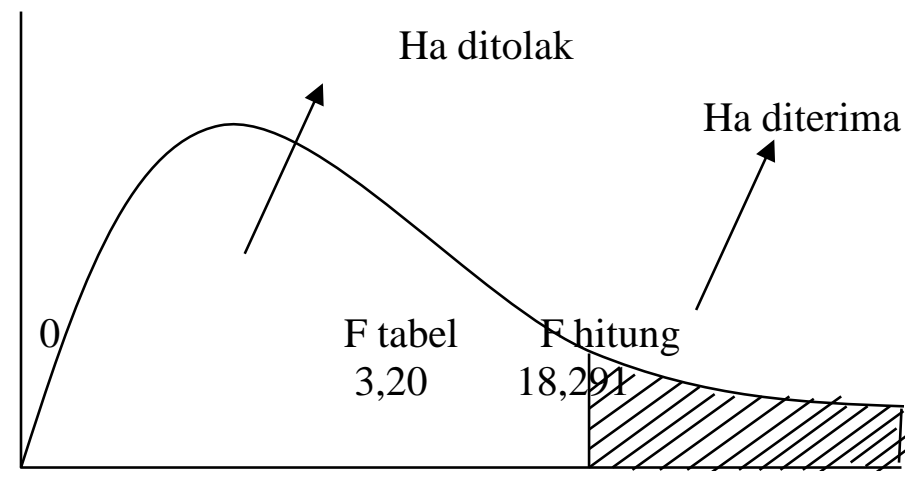

Gambar 4. Kurva distribusi variable uji $\mathrm{F}$

\section{Uji Dominan}

Pengujian hipotesis variabel bebas yang paling berpengaruh terhadap kepuasan konsumen dapat disajikan dalam tabel berikut ini :

Tabel 9. Uji Dominan Variabel Penelitian

Coefficients $^{\mathbf{a}}$

\begin{tabular}{|c|c|c|c|c|c|c|}
\hline \multirow{2}{*}{\multicolumn{2}{|c|}{ Model }} & \multicolumn{2}{|c|}{$\begin{array}{c}\text { Unstandardized } \\
\text { Coefficients }\end{array}$} & \multirow{2}{*}{$\begin{array}{c}\text { Standardized } \\
\text { Coefficients } \\
\text { Beta }\end{array}$} & \multirow[b]{2}{*}{$\mathrm{t}$} & \multirow[b]{2}{*}{ Sig. } \\
\hline & & B & Std. Error & & & \\
\hline \multirow[t]{3}{*}{1} & (Constant) & $5.185 \mathrm{E}-17$ & .108 & & .000 & 1.000 \\
\hline & Jam Kerja & .591 & .112 & .591 & 5.289 & .000 \\
\hline & $\begin{array}{l}\text { Disiplin } \\
\text { Kerja }\end{array}$ & .200 & .112 & .200 & 1.792 & .080 \\
\hline
\end{tabular}

a. Dependent Variable: Stres Kerja

Kesimpulan yang bisa diambil dari data diatas adalah menunjukkan pengaruh nilai positif variabel bebas terhadap variabel terikat. Dengan nilai berpengaruh variabel jam 
kerja $\left(\mathrm{X}_{1}\right)$ sebesar 5,289 dan variabel disiplin kerja $\left(\mathrm{X}_{2}\right)$ sebesar 1,792 maka kesimpulannya adalah nilai variabel jam kerja tersebut lebih besar dari nilai variabel disiplin kerja, dengan demikian hipotesis penelitian ini terbukti bahwa variabel jam kerja berpengaruh paling dominan terhadap stres kerja karyawan.

\section{Koefisien Determinasi $\left(\mathbf{R}^{2}\right)$}

Koefisien determinasi digunakan untuk mengetahui kemampuan variabel indenpenden dalam menjelaskan variabel dependen. Besarnya nilai koefisien determinasi dapat dilihat pada $\mathrm{R}$ Square dan dan dinyatakan dalam persentase. Berikut ini adalah ukuran konstribusi pengaruh jam kerja $\left(\mathrm{X}_{1}\right)$ dan disiplin kerja $\left(\mathrm{X}_{2}\right)$ terhadap stress kerja karyawan (Y).

Tabel 10. Hasil Uji Koefisien Determinasi

Model Summary ${ }^{b}$

\begin{tabular}{|l|r|r|r|c|}
\hline Model & $\mathrm{R}$ & R Square & Adjusted R Square & $\begin{array}{c}\text { Std. Error of the } \\
\text { Estimate }\end{array}$ \\
\hline 1 & $.662^{\mathrm{a}}$ & .438 & .414 & .76566788 \\
\hline
\end{tabular}

a. Predictors: (Constant), Disiplin Kerja, Jam Kerja

Berdasarkan data diatas dipengaruhi variabel jam kerja $\left(\mathrm{X}_{1}\right)$ dan disiplin kerja $\left(\mathrm{X}_{2}\right)$ terhadap stress kerja karyawan (Y), menunjukan nilai $\mathrm{R}=0,662$ yang berarti bahwa variabel jam kerja dan disiplin kerja berpengaruh terhadap stres kerja karyawan. Nilai koefisien determinasi menunjukkan nilai 0,438 , dari hasil tersebut berarti seluruh variabel bebas yaitu jam kerja dan disiplin kerja mempunyai kontribusi sebesar 43,8\% terhadap variabel stres kerja karyawan (Y) dengan tingkat ketetapannya cukup dan sisahnya sebesar 56,2\% dipengaruhi faktor - faktor lain yang tidak masuk dalam penelitian.

\section{KESIMPULAN}

Berdasarkan hasil penelitian dan pembahasan yang telah dilakukan maka dapat ditarik kesimpulan sebagai berikut:

1. Ditemukan hasil analisis regresi linier berganda, yaitu $Y=5,185 \mathrm{E}-17+0,591 \mathrm{X}_{1}+$ $0,200 \mathrm{X}_{2}+\mathrm{e}$

2. Berdasarkan hasil secara persial diketahui bahwa hasil $t_{\text {hitung }}$ dan $t$ tabel yang menunjukkan bahwa variabel jam kerja $\left(\mathrm{X}_{1}\right) \mathrm{t}_{\text {hitung }}(5,289)>\mathrm{t}_{\text {tabel }}(2,011)$. kerja mempunyai pengaruh yang positif terhadap stres kerja karyawan (Y), Hal ini juga diperkuat dengan nilai signifikan $0.000<0,05$. Artinya variabel jam kerja berpengaruh signifikan terhadap stres kerja karyawan pada Kantor Kecamatan Kapongan Situbondo. Sedangkan variabel disiplin kerja $\left(\mathrm{X}_{2}\right) \mathrm{t}_{\text {hitung }}(1,792)<\mathrm{t}_{\text {tabel }}(2,011)$, Hal ini juga diperkuat dengan nilai signifikan 0,080>0,05 artinya variabel Disiplin kerja tidak berpengaruh signifikan terhadap stress kerja karyawan pada Kantor Kecamatan Kapongan Situbondo. Berdasarkan perhitungan secara simultan diketahui bahwa hasil $\mathrm{F}$ hitung dengan $\mathrm{F}$ tabel, nilai $\mathrm{F}_{\text {hitung }}>\mathrm{F}_{\text {tabel }}(18,291>3,20)$. Dengan demikian maka dapat disimpulkan bahwa $\mathrm{H}_{\mathrm{a}}$ diterima dan $\mathrm{H}_{\mathrm{o}}$ ditolak yang terdiri dari jam kerja dan disiplin kerja berpengaruh secara simultan terhadap stres kerja karyawan. Sedangkan Berdasarkan hasil uji dominan kesimpulan yang bisa diambil adalah menunjukkan pengaruh nilai positif variabel bebas terhadap variabel terikat. Nilai berpengaruh variabel jam kerja $\left(\mathrm{X}_{1}\right)$ sebesar 5,289 dan variabel disiplin kerja $\left(\mathrm{X}_{2}\right)$ sebesar 1,792 maka kesimpulannya adalah nilai variabel jam kerja tersebut lebih besar dari nilai 
variabel disiplin kerja, dengan demikian hipotesis penelitian ini menyatakan bahwa variabel jam kerja berpengaruh paling dominan terhadap stres kerja karyawan.

3. Nilai koefisien determinasi menunjukkan nilai 0,438 , dari hasil tersebut berarti seluruh variabel bebas yaitu jam kerja dan disiplin kerja mempunyai konstribusi sebesar 43,8\% terhadap variabel stress kerja karyawan (Y) dengan tingkat ketetapannya cukup dan sisahnya sebesar 56,2\% dipengaruhi faktor - faktor lain yang tidak masuk dalam penelitian.

\section{UCAPAN TERIMA KASIH}

Terimakasih kepada Pusat Penelitian dan Pengabdian kepada Masyarakat (P3M) UNARS atas kesempatan pendanaan internal yang diberikan kepada peneliti. Kegiatan ini juga berkat dukungan pihak Kecamatan Kapongan yang telah bersedia berpartisipasi meluangkan waktu untuk memberikan data serta mahasiswa yang telah membantu kelancaran penelitian.

\section{DAFTAR PUSTAKA}

Harrington, J.M. (2001). Health Effect of Shift Work and Extended Hours of Work. Journal of Occupational and Environmental Medicine. University of Birmingham.

Imatama, Zuhrina. 2006. Pengaruh Stres Kerja Terhadap Kinerja Karyawan di Lembaga Pendidikan Perkebenan (LPP) Kampus Medan.Medan : Program Strata-1 Jurusan Manajemen Universitas Sumatera Utara.

Malthis, Robert L dan Jhon H. Jackson. 2002. Manajemen Sumber Daya Manusia. Jakarta: Buku 1, Salemba Empat.

Mangkunegara, Anwar Prabu A.A. 2001.Manajemen Sumber Daya Manusia Perusahaan. Bandung : PT Rosda Karya.

Maurits, L.S. \& Widodo, I.D. 2008.Faktor dan Penjadualan Shift Kerja. Jakarta: Jurnal Teknoin Volume 13, Nomor 2.

Poerwadarminta, W.J.S. 2006. Kamus Umum Bahasa Indonesia. Jakarta: Balai Pustaka

Rivai. 2004. Penilaian Prestasi Kerja Teori dan Praktek. Jakarta. PT. Ganudra Pustaka Utama.

Robbins, Stephen P. 2002. Pengaruh Jam kerja dan Stres Kerja Terhadap Disiplin Kerja . Jakarta: Prehallindo.

Sari. 2003. Pengaruh Jam kerja dan Stres Kerja Terhadap Disiplin Kerja . Jakarta: PT. Indek Kelompok Gramedia. 